\title{
CSR and Environmental Responsibility: Motives and Pressures to Adopt Green Management Practices
}

\author{
Kathy Babiak*1*1 and Sylvia Trendafilova ${ }^{2}$ \\ ${ }^{1}$ University of Michigan, School of Kinesiology, Ann Arbor, MI,USA \\ ${ }^{2}$ University of Tennessee Knoxville, Department of Exercise, Sport and Leisure Studies Knoxville, TN, USA
}

\begin{abstract}
This paper examines the diffusion of environmental management initiatives in business and the motives and pressures reported by senior executives to adopt these practices in one industry. We frame these sustainable practices under the umbrella of corporate social responsibility (CSR) and examine the causal drivers of environmental behavior. This study used a mixed-methods approach and included a survey and 17 in-depth interviews with professional sports team and league executives. Data revealed both strategic and legitimacy motives to adopt environmental management practices. More specifically, the analysis suggested that strategic motives were the primary reason for adopting an environmental CSR focus. Motives to address institutional pressures were also found, although to a lesser extent. The paper discusses the role and relevance environmentally focused CSR plays in professional sport organizations in North America and presents suggestions for future research in this area. Copyright (C) 2010 John Wiley \& Sons, Ltd and ERP Environment.
\end{abstract}

Received 3 September 2009; revised 12 January 2010; accepted 19 January 2010

Keywords: environmental sustainability; corporate social responsibility; organizational change; professional sport

ORPORATE SOCIAL RESPONSIBILITY (CSR) IS PLAYING AN INCREASINGLY IMPORTANT ROLE IN BUSINESS TODAY, AND economic, political and social factors are shaping CSR activities around the world (Baughn et al., 2007). Some authors describe CSR as a set of actions aimed to further some social good, beyond the explicit pecuniary interests of the firm, that are not required by law (Carroll, 2000; McWilliams and Siegel, 2000) and as 'practices that improve the workplace and benefit society in ways that go above and beyond what companies are legally required to do' (Vogel, 2005). In this paper, we argue that environmentally responsible business practices are an element of CSR in that they are often initiated for reasons other than to make a firm money (but sometimes do), they are not (always) required by law, and they benefit society. This paper follows a call by Margolis and Walsh (2003) to explore contextual influences that lead organizations to be socially responsible focusing specifically on corporate environmental responsibility.

Although CSR practices have drawn substantial interest from practitioners and academics, the motives driving those practices have received little attention in the academic literature - particularly from an empirical perspective. Indeed, as Williamson et al. (2006) argued, there is a lack of work examining the causal drivers of environmental behavior, particularly for small and medium enterprises (SMEs), and we need to better understand the mechanisms

*Correspondence to: Kathy Babiak, University of Michigan, School of Kinesiology, 1402 Washington Heights, Ann Arbor, MI 48109, USA. E-mail: kbabiak@umich.edu 
that foster how and why firms behave environmentally. Additionally, given the changes taking place in society regarding the role businesses play in addressing social issues, Vidaver-Cohen and Simcic Brønn (2008) argued that the parameters of legitimacy for many businesses have changed in the new millennium, and that there may be both moral and strategic imperatives for corporate efforts to strengthen the communities in which they operate. They thus explain that motives for engaging in CSR may be changing (from a peripheral practice to a more strategic function and embedded into the values of the organization) and that the motives and role CSR plays in business needs to be re-examined.

Given the growing role of environmental sustainability as a focus for corporations across diverse industries, the purpose of this paper is to uncover the motives leading organizations in one industry - major league professional sport in North America - to behave in an environmentally responsible manner. Given that these practices are relatively new in professional sport, this exploratory research was guided by the following questions: (I) what external conditions and internal pressures lead organizations to address the environment as a priority?; and (2) how do the external conditions/internal pressures and the motives reported determine the types of environmental initiatives adopted - whether they are high commitment or low engagement? By studying these issues in depth, we hope to contribute to our understanding of the adoption and diffusion of environmental responsibility for organizations both within and outside the sport industry.

\section{Literature Review}

\section{Motives for Engaging in CSR}

The topic of CSR is receiving growing attention in the academic literature as the role that CSR plays in business has grown (Margolis and Walsh, 2003; Orlitzky et al., 2003; Gouldson, 2006; Campbell, 2007; Siegele and Ward, 2007). Although academics have tended to focus on identifying the link between financial and social performance (Margolis and Walsh, 2003), consistent with the approach adopted in this paper, Campbell (2006; 2007) argued that there are a number of mitigating factors in the relationship between organizations and society which help to explain why companies would behave in socially responsible ways. Campbell (2007) believed that we need to 'pay more attention to the institutional mechanisms that may influence whether corporations act in socially responsible ways or not'. He argued that institutional theory may be useful in understanding the adoption and implementation of CSR behaviors.

Matten and Moon (2008) noted that particularly with CSR, the "motives of managers, shareholders, and other key stakeholders shape the way corporations are governed... and institutional theory brings interdependencies between and interactions among stakeholders into the analysis, which is vital to understanding CSR, given its societal orientation'. Institutional theorists (Galaskiewicz and Burt, I99I; Doh and Guay, 2006; Campbell, 2007; Matten and Moon, 2008; Scott, 2008) have maintained that several relevant institutional forces may be at play in determining the level to which a company may adopt socially responsible business practices. In fact, institutional forces influencing CSR may result in the homogenization of institutional environments. These changes are expressed in regulative, normative, and cognitive processes leading to increasingly standardized and rationalized practices in organizations across and within industries (DiMaggio and Powell, I99I; Scott, 2008).

Suchman (I995) discussed legitimacy as the 'generalized perception or assumption that the actions of an entity are desirable, proper, or appropriate within some socially constructed system of norms, values, beliefs, and definitions'. Suchman (I995) suggested 'legitimacy affects not only how people act toward organizations, but also how they understand them. Thus, audiences perceive the legitimate organization not only as more worthy, but also as more meaningful, more predictable, and more trustworthy'. The CSR/business connection suggests that attaining legitimacy may improve a company's ability to compete for resources, garner stakeholder approval (Rao, I994), and provide a bank of goodwill during times of crisis (Godfrey and Hatch, 2007; Deephouse and Suchman, 2008).

Because of this link with legitimacy, institutional theory has been viewed as an appropriate lens through which to explore CSR (Doh and Guay, 2006; Campbell, 2006; 2007; Matten and Moon, 2008). Campbell (2007) asked whether the motives driving CSR were 'purely voluntary and dependent on having honorable people in charge, or is there something more to it?', and provided several theoretical propositions as to why companies might be driven 
to engage in CSR in light of institutional theory. He maintained that a number of broad institutional and economic conditions determine whether CSR behavior is likely to occur and suggested that corporations will likely act in socially responsible ways if strong and well-enforced regulations are in place, along with well-organized and effective industrial self-regulations (Campbell, 2007). In addition, conditions which provide for monitoring corporations' behaviors, such as independent organizations, are considered favorable for ensuring responsible behavior. The likelihood of acting responsibly increases when normative standards, widely accepted by society, support such behaviors. Lastly, corporations' behaviors are affected by how community leaders and other stakeholders perceive their efforts and whether they engage in institutionalized dialogue among each other. The importance of these institutional conditions is that they influence corporations' motivation behind adopting socially responsible behaviors.

While the quest for legitimacy may be a strong motivator for organizations to engage in CSR, other plausible explanations should also be considered. In much of the literature, CSR has been treated as being separate from more traditional, strategic initiatives and outcomes. There has, however, been some recent work pointing to the potential synergy between social and financial performance. Prominent among such work is that of Bruch and Walter (2005) and Porter and Kramer (2006) which argued for a more closely aligned fit between a company's core strategy and its CSR efforts. In line with this argument is the work of Sarkar (2008), pointing out that business practices in relation to the environment have evolved and the trend now is for transitioning from environmental management to environmental strategy. Sarkar (2008) recognized 'that the relation between environmental and economic interests is a balance of purely competitive and purely cooperative factors'.

Vidaver-Cohen and Simcic Brønn (2008) predicted that there would be changes in motives for businesses engaging in CSR worldwide, some associated with moral/normative legitimacy concerns, others with more pragmatic objectives. Similarly, Fombrun et al. (2000) believed that companies are increasingly coming to the realization that a strategically integrated CSR portfolio 'helps a company build reputational capital... By doing good, managers generate reputational gains that improve a company's ability to attract resources, enhance its performance and build competitive advantage'. Gimenez Leal et al. (2003) support this view and claim that there is a direct and positive relationship between the adoption of environmental practices and the company's competitive position. A number of theorists have maintained that companies would be motivated to adopt an industry-driven strategic approach to CSR, focusing on activities that expressed special industry competencies while simultaneously strengthening their communities, and that intersectoral partnerships with non-governmental organizations (NGOs) and government agencies may help companies more effectively accomplish social goals (Waddell, 2000; Waddock and Smith, 2000; Vidaver-Cohen and Simcic Brønn, 2008).

The International Organization for Standardization (ISO) has launched the development of standardized guidelines for social responsibility (ISO 26000). The ISO claims that '... the need for organizations in both public and private sectors to behave in a socially responsible way is becoming a generalized requirement of society' (iso.org, 2009). The standard will be usable for organizations of all sizes, in countries at every stage of development. These proposed standards would address the social responsibility not only of business corporations, but of all types of organization. In this paper we use CSR as discussed in the academic literature as a concept that refers to social responsibility for organizations beyond business corporations. Specifically, the context of our study, professional sport organizations, would fall into the guidelines of social responsibility set out by ISO 26000 .

\section{Management, CSR, and Environmental Sustainability}

Recent research has examined the adoption of environmental management practices by organizations indicating that companies are increasingly paying attention to their impact on the environment and adopting management practices to ameliorate or reduce their negative impact on the environment (Williamson et al., 2006; Welford et al., 2007; Sarkar, 2008; Wahba, 2008). The natural environment is increasingly being viewed as a pillar of CSR. Research on CSR and environmental sustainability in the management literature is converging because of shared environmental, economic, and social concerns (Montiel, 2008). In I995, Shrivastava identified a shift in businesses to 'ecocentric' management, highlighting an increase in ecologically sustainable organization-environment relations. Organizations operating under the ecocentric paradigm 'establish harmonious relationships between their natural and social environments. They seek to systematically renew natural resources and to minimize waste and 
pollution' (Shrivastava, I995). A number of variables have been used to identify and assess environmental responsibility, including the existence of pollution abatement programs, the extent to which an organization conserves natural resources, involvement in voluntary environmental restoration, eco-design practices, or the systematic reduction of waste and emissions from operations (Montiel, 2008).

Montiel (2008) suggested that current research seems to show a shared environmental and social concern for activities addressing environmental responsibility. Regulatory compliance and social responsibility to address environmental impacts are components of corporate environmental management, which Montiel argued, is driven by legal and/or social sanctions. However, the underlying thread in the literature on environmental strategy is that through a complex web of constituents, whether customers, shareholders, investors or employees, environmentalism becomes transformed from something external to the market environment to a core objective of the firm.

In recent years, the environment has been one of the factors of greatest interest in terms of the market's attitude toward CSR (Bird et al., 2007; Wahba, 2008). Indeed, some reports point at improved financial performance as a result of environmental performance development (Klassen and McLaughlin, I996). Similarly, Welford et al. (2007) and Kassinis and Vafeas (2006) found the environment to be the most important concern for stakeholders in a company's CSR efforts. Wahba (2008) explored the moderating effect of financial performance on the relationship between corporate environmental responsibility and institutional investors and concluded that environmental responsibility had a positive and significant effect on institutional ownership, although this was the case only when financial performance was high. Another perspective of a corporation's role in environmental management suggests that top management's green commitment is a factor, among others, influencing the formulation of different types of corporate environmental practices (Lee and Ball, 2003).

\section{Method}

The research described next examines the themes discussed above in the setting of professional sport teams and leagues in North America. We argue that this context is appropriate given the relative newness of environmental business practices in sport which thus offers a unique opportunity to examine the pressures driving these organizational practices in this setting. We provide an overview of the research setting. The data collection and analysis are also presented in this section.

\section{Research Context: CSR, Sport, and the Environment}

The landscape of North American professional sport has changed dramatically over the past 25 years. While little empirical research has been conducted on the intersection of CSR and sport, one look at a professional sport team's webpage and other communication vehicles indicates that CSR has become an important part of these organizations' business operations. Although sport teams have been involved in their local communities for decades, we know little about the relevance, importance, and impact of socially responsible practices to the organizations themselves, to the individuals they intend to benefit, and to the league-governing bodies. Considering the fact that the sport industry is rapidly growing and this trend is likely to continue in the future (Humphreys and Ruseski, 2008), professional sport in North America presents a rich context in which to study CSR because organizations in the industry are increasingly becoming involved in sustainability efforts. While some leaders of sport organizations believe that 'doing good is the right thing to do', others believe that 'doing good is good business' (Mintzberg, I984), being motivated by pragmatic, traditional business, outcomes (e.g., to counter negative media scrutiny, and to be good corporate citizens worthy of desired tax breaks and subsidies from government (to build or refurbish stadia, build access roads)). Further, and perhaps more importantly, there has been little academic/empirical research conducted in the area, leaving an opportunity for theoretical and practical contributions.

Academic consideration is now being given to the unique context in which sport operates and some argue that the nature and role CSR plays in sport may be different than in other industries (Babiak and Wolfe, 2006; 2010; Smith and Westerbeek, 2007; Brietbarth and Harris, 2008; Sheth and Babiak, 2010;). Smith and Westerbeek (2007) for instance, claimed that sport, broadly defined, has a number of unique factors that may positively affect 
the nature and scope of partner corporations' CSR efforts including: mass media distribution and communication power, youth appeal, positive health impacts/association, social interaction, and sustainability awareness.

Scholarly work in the area of sport and environmental management has been rather scarce and mostly focused on outdoor recreational sports and their impact on the ecosystem (Font et al., 200I; McMillan et al., 2003; Muller et al., 2004; Shively et al., 2008). The literature on professional sport and the environment is even scarcer. Some research has addressed the environmental problems associated with large-scale sport events, such as the Football Association Cup Final, by describing the ecological footprint of this event, and highlighting the high impact mega sport events have on the environment (Collins et al., 2007). A professional sport team's day-to-day operations often require heavy amounts of energy consumption, so it has been argued that green practices can make a substantial positive impact on the environment (Covello, 2008) in addition to providing substantial cost savings and other benefits to a sport organization. As a starting point, this paper will examine professional sport in North America, in particular the motivation behind the environmental initiatives professional sport teams and leagues have established in their effort to raise awareness, improve efficiencies in their operations, and to fulfill their corporate social responsibilities in this area.

\section{Data Collection}

To understand the extent to which environmental practices are adopted and the motives driving corporate environmental responsibility, we investigated teams in five professional sport leagues in North America, i.e., the: National Basketball Association (NBA), National Football League (NFL), Major League Baseball (MLB) and the National Hockey League (NHL) and Major League Soccer (MLS).

We used three primary approaches to data collection. First, we conducted a survey with professional sport teams and followed this with in-depth interviews with team and league executives. Finally, we examined the web pages of the organizations represented by the interview participants.

\section{Survey}

The population of the survey included community relations and foundation directors of teams in the NFL $(32$ teams), NBA (30 teams), NHL (30 teams), MLB (30 teams) and MLS (I5) for a total of 137 organizations. The survey was part of a larger study on CSR in sport, and its purpose was exploratory - to assess and determine areas of priority, to uncover executives' perceptions and expectations regarding the role and relevance of CSR in sport, and to identify the drivers, pressures, and motives underpinning these activities. The intent of this survey was to ascertain preliminary themes which would then be examined more thoroughly through the in-depth interviews. Surveys were sent to executives via email and hard copy. Participants were offered the choice of medium by which to respond. Three reminders were sent (via email and hard copy). The responses to surveys that were sent back via mail were entered manually into SPSS. The instrument used in this study was a 39-item questionnaire that asked open-ended, rank-order, and Likert-scale questions to determine how sport executives view and practice CSR in their organizations and the motives underpinning their decisions to adopt environmental practices. Several questions each explored the same concept to increase internal validity. The environmental portion of the survey consisted of seven questions related to motives, pressures and focus of environmental management practices. A total of 23 respondents completed this portion of the survey - a I7\% response rate.

\section{In-depth interviews}

In-depth interviews were conducted with i7 team and league senior executives who were all involved in the decision-making for their team or league's environmental efforts. Table i indicates the breakdown of team/league executives interviewed for this study.

The interviews ranged from 30 to 90 minutes. These interviews were conducted by both authors, some in person and others via telephone. Respondents answered questions pertaining to the extent of involvement in environmental CSR, and the motives behind their organization's involvement in environmental initiatives. Each interview was based on the seminal question of our research: 'Why is your organization concerned about the environment?' We then further questioned the interviewees concerning the motives behind adopting environmental initiatives; which 


\begin{tabular}{|c|c|c|}
\hline League & \# of Respondents & Positions \\
\hline NBA & 5 & $\begin{array}{l}4 \text { - Community Relations Directors (Team) } \\
1 \text { - Sr VP of Community Relations (League) }\end{array}$ \\
\hline NFL & 4 & $\begin{array}{l}1 \text { - Sr Director of Marketing (League) } \\
1-\text { Environmental Director (League) } \\
1 \text { Sr Director of Marketing (Team) } \\
1 \text { - Community Relations Director (Team) }\end{array}$ \\
\hline $\mathrm{NHL}$ & 3 & $\begin{array}{l}1 \text { - Sr VP of Community Relations (League) } \\
2 \text { - Community Relations Directors (Team) }\end{array}$ \\
\hline MLB & 5 & $\begin{array}{l}1 \text { - Sr Director of Marketing (League) } \\
1 \text { - Sr VP of Community Relations (League) } \\
2 \text { - Community Relations Directors (Team) } \\
1 \text { - Director of Operations/Facility (Team) }\end{array}$ \\
\hline TOTAL & 17 & \\
\hline
\end{tabular}

Table 1. Breakdown of interview respondents

stakeholders placed these expectations on them; and what benefits and advantages sustainability-related efforts provide to their organization. Participants were also encouraged to discuss the challenges and barriers that they perceived regarding implementation of their organizations' environmentally friendly efforts. The interviews allowed for an in-depth understanding of the participants' perspectives concerning their organization's involvement in environmental initiatives. The interviews were audio recorded, transcribed verbatim, and reviewed by the authors and sent to the participants themselves to be reviewed for accuracy and clarity.

\section{Webpage Analysis}

Following the interviews, we examined the web pages and environmental programs of the sport organizations represented by the respondents. Involvement in environmental initiatives was classified as either low engagement or high commitment (Greenwood, 2007). Low engagement efforts are initiatives which are not sustained (i.e., an 'Easy to be Green' night, or 'Carbon Neutral' games), which serve to highlight particular circumstances (i.e., Earth Day), or which were initiated and promoted through a player or his own foundation (e.g., the Steve Nash Foundation). High commitment efforts are initiatives that teams have started that are ongoing, that require substantial resources (financial, human, technological), and/or that focus on broad organizational operations (e.g., the Houston Astros' company-wide greening initiative, Philadelphia Eagles' corporate and messaging efforts - i.e., installing solar panels or wind turbines to power stadia or practice facilities).

\section{Data Analysis}

Quantitative data were imported into SPSS I7.0 where frequencies, means, and standard deviations were computed. Interview transcripts were analyzed using Atlas.ti. Initial coding was conducted by both authors, with higher order themes derived from the CSR and environmental management literature. The data analysis then followed inductive reasoning techniques or 'open coding' where patterns and themes were discovered in the data and a coding scheme was developed. Recurring themes identifying the motives and pressures underpinning the adoption of environmental management efforts emerged. During this phase, the researchers read through three of the transcripts separately and identified meaning units (i.e., words, phrases or paragraphs that captured the meaning in each quotation). Based on these meaning units, we inductively identified lower order themes and further subthemes within each of the higher order themes. To enhance trustworthiness, we then exchanged notes and discussed various interpretations and nuances of the themes (Patton, 2002; Bazeley, 2007). Any discrepancies in meaning were resolved through discussion and clarification. All textual data were then analyzed once again with the revised codes. Any issues regarding coding were discussed, debated and agreed upon by members of the team during research meetings. A final code book including codes for all environmental responsibility motives was created. The interview transcripts and documents were then re-analyzed with the updated codes and a final review for consistency and accuracy was conducted. 


\section{Results and Discussion}

Our data analysis indicated that executives responsible for decision-making regarding sustainable management practices considered multiple motives for engaging in environmental CSR, primarily seeking legitimacy by conforming to institutional pressures and expectations and taking advantage of the strategic opportunities offered through these types of activities. Survey results for instance, indicated that $43 \%$ of executives felt that being viewed as a 'good citizen' was one of the most influential factors causing (sport) organizations to address environmental issues, and $39 \%$ felt that to be environmentally responsible was the societal norm now.

Both our survey and interview data indicated that corporate environmental responsibility is something to which sport businesses are increasingly paying attention from a strategic perspective. It appears that sport organizations are recognizing that their operations have a significant negative impact on the environment, and that by proactively addressing these problems, they may be averting legal recourse, saving money, as well as building stronger relationships with key stakeholders such as customers, fans, local communities, local, state, and federal governments, and corporate partners. Thus, being environmentally conscious may in fact be good for business. These findings support those of Williamson et al. (2006) who showed that factors related to the performance of the business (i.e., cost reductions and efficiencies) and regulation considerations motivated environmental CSR.

As the data presented in Table 2 suggest, these strategic motives for engaging in environmental CSR activities are believed to provide (sport) organizations with advantages in different areas (i.e., enhancing reputation, addressing demands and expectations of customers, mitigating negative media reports, and developing a stronger network of partners resulting in deeper linkages into the communities in which these teams and leagues operate). Our respondents indicated that addressing green management issues allowed them to simultaneously be good citizens and contribute to their business objectives (in this case, green management was viewed as a CSR practice which could positively impact the bottom line). A number of executives discussed the cost savings associated with being environmentally conscious in facility operations in particular. Turning off lights at practice and game facilities, adjusting the thermostat, and using solar or wind power were all identified as substantial cost saving measures. Although the financial incentives of adopting environmentally friendly practices are recognized, survey results indicated that $57 \%$ of respondents fear that inadequate financial and human resources prevent them from implementing any sustainable programs. Table 2 highlights representative quotations in each of the categories (i.e., legitimacy motives, strategic motives).

Consistent with Austin (2003), we also found evidence that the creation of strategic collaborations is a strong motivating force to address environmental CSR. Most of the executives identified the potential financial opportunities that green management provided them through non-traditional partnership or marketing channels - like linking with corporate sponsors that have an interest in the environment, or establishing relationships with partner experts to increase operational efficiency. In fact, $61 \%$ of the survey respondents indicated that they have established collaboration efforts with different partners. Additionally, by engaging in environmentally focused CSR, it allowed sport businesses to reach out to nonprofit groups in the community. This in turn could not only expand the spectrum of relationships professional sport organizations establish in the community, but also could be an indicator of higher levels of commitment to a cause, thus making CSR environmental initiatives more strongly embedded in the organizational culture and strategic practices.

Data analysis indicated that a number of league wide environmentally focused initiatives were designed as strategic alliances with experts and consulting groups who provide knowledge and insight. For example, the NBA and MLB's partnership with the National Resources Defense Council (NRDC, a national, non-profit organization of scientists, lawyers and environmental specialists dedicated to protecting public health and the environment), and NHL's relationship with GreenLife (a company that develops comprehensive global solutions to help firms 'go green') illustrate such associations. Although these efforts are in an early stage of development, practices with similar focus are being shown across different sport leagues for instance, having 'Green' or 'Carbon Neutral' games, offsetting carbon emissions from team travel, recycling programs, and exposing fans to environmental awareness messages.

Executives also reported being motivated to address the environment in order to conform to external institutional pressures, such as acquiescence to government directives (e.g., facility construction). About 30\% of our survey 


Motive Content $\quad \begin{aligned} & \text { Representation } \\ & \text { in Data }\end{aligned}$

\section{Conform to \\ Institutional \\ Pressures \\ (Legitimacy) \\ In line with societal norms, values, and expectations \\ Mimetic/ \\ Associative forces (i.e., other teams, leagues, and businesses outside professional sport are doing it)}

Scrutiny/Regulation

\section{Strategic Motives} (government directives, avoid scrutiny from media)

TOTAL: 203

$(22 \%) *$

107

63

33

TOTAL: 453

$(49 \%) * *$

213

resources to be environment leader/first mover
To develop partner networks
- People are talking about the environment more and more and expect companies to be responsible in what they do. Everyone in the country has jumped on green and it has been great for us. It's beyond sport. (NBA Executive)

- Why are sports teams and leagues addressing environmental issues? Well, society is increasingly becoming more aware of the environment and sport is an integral part of modern culture so we're all just part of the same ball of wax here. (NFL Executive)

- There is sharing from team to team. One team might say we just introduced this fantastic water-saving measure and because of equipment sharing and the fact that we work in the same industry, there is the ability to share best practices, and that is happening both informally and formally. (MLB executive)

- I have noticed that there are other teams in other leagues who are doing it. I don't know if it is the in thing to do these days, or if it's the politically correct thing to do, but from what l've seen, it's a fairly close network, and there is a lot of communication that goes on between most of the teams. A lot of what you find is a copycat thing - if I see somebody in Philadelphia doing something for a foundation or a fundraiser or something that went well, I could try and pull it off in (City) and there's a good chance that I'll have the same success. I would hope that people are doing it because they really want to help the environment, but I think a lot of it is probably looking around and seeing other teams getting involved and it's making them pay attention and taking it into consideration. (NHL executive)

- People probably don't want to say too much or admit it, but that's one reason why you're seeing more people doing it. Some of them are afraid to get 'outed' by the media that they're not doing it or not really environmentally sensitive, which is okay because people are being influenced to do the right thing. (MLB executive)

- People who are really leading the way and saying I'm doing this because I believe it have an opportunity be a good citizen, but also to take a little more advantage of it perhaps from a marketing or strategic standpoint. There are others out there that just see this as a marketing opportunity too, it's a marketing opportunity of the day is sustainability and let's position ourselves in this marketplace so we can generate more business (MLB Executive)

- How do we position ourselves in the marketplace and can we take advantage of that and in some cases with the marketing relationship which packages something that everybody gains from it and public awareness about the issue and our involvement has increased. (MLB Executive)

- We talk about things that we can do on a business level but also areas where we can educate our fans, build awareness, interact more with our partners. We do take a multi-pronged approach to this program. (NFL Executive)

- Partnerships played an important role in our efforts... The partnerships we form are all strategic partnerships with organizations in the community. It was something that was increasingly important to our business partners and the community and we thought that we had an opportunity to take advantage of that and start some initiatives of our own, internally. (NFL executive) 


Motive Content $\quad$ Representation Sample Quotation

in Data

\author{
Financial \\ opportunity - \\ new marketing \\ opportunities/ \\ savings \\ Image \\ enhancement

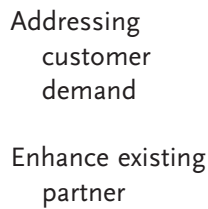

Targeted - tailored to needs of own market
- The environment is not an area that sports teams would normally employ an expert in. In house, we have legal people, marketing people, we have broadcasters, we have television production groups, community relations, and so on, but nobody knows anything about the environment. They know what they have seen on the news and they know what the popular phrases of the day are, but I don't know anybody outside of the people I have talked to at Earth Day Network and E-4 that I would consider to be experts. We may be learning a lot and eventually become experts, but it's something that is very far removed from what we do. And that has been the mentality of sport organizations - it is what we are used to doing. The environmental issues are a bit of an odd fit for us now - which is why partners are so important. (NHL Executive)

- To give you an example, previously we had plastic beer bottles in our stadium, and of course you can recycle those, but what we found was that switching to aluminum cans for our beer products in the stadium, not only was it a more efficient product to recycle, we actually received higher revenues from recycling aluminum over plastic. So we worked with our vendors to get aluminum cans and made the switch this year. So it was a smart environmental decision, but it was a smart business decision because it increased the revenue stream from the recycled products. (NFL Executive)

- As far as someone benefiting, it is simple, it is the right thing to do, but we also get fantastic publicity out of this. We've been featured in a number of national publications, national TV, local TV, local publications, it is great free publicity that the (MLB team) are a leader in green energy. (MLB executive)

- We have seen the demand and fantastic support from baseball fans in every market across the board. I think there's real potential and excitement there. It is very much embraced now and we have had a lot of positive response. (MLB Executive)

- Wanting to be responsive and be responsible while at the same time doing it in such a way that helps us to remain competitive and financially viable was important. We wanted information on how this affects the bottom line. We would all like to do it because it's the right thing, but too often that is not the kind of motivation that will get some of these projects done. Sometimes you do these things because it is something that your business partner wants to do and they are willing to pay you to take on some of these projects. Sometimes you do them because it just makes sense. (NFL executive)

- You need to look at the city infrastructure and the environmental infrastructure in a city. Some cities have very robust solid waste management programs that a commercial venue like a stadium can hook into. Others may have a terrific residential recycling program, but virtually no commercial recycling program so each city needs to do things that are targeted to what their resources, partners and capabilities allow. (NFL Executive)

Table 2. Reported motives to adopt green CSR practices in professional sport

$*$ Represents total number of coded quotations for institutional motives reported by executives. Percentage is overall percentage of all coded quotations in data set.

$* *$ Represents total number of coded quotations for strategic motives reported by executives. Percentage is overall percentage of all coded quotations in data set. 
respondents revealed that they have a management representative solely assigned the responsibility for assuring and facilitating compliance with environmental laws and regulations and implementing green practices on both the management side and the 'on field' side of the business. In North America, although there are no laws or regulations overseeing the environmental practices and business operations for sport teams and leagues, federal, state and local green building initiatives and mandates are increasingly becoming a requirement for publicly funded projects, and new construction of sport arenas and stadia are not exempt. These green building initiatives and mandates are a relatively recent occurrence. The first such mandate for a Major League Baseball stadium was the Washington Nationals' stadium, which opened in March of 2008. The Washington DC Metro Council required environmental certification of the stadium as part of their financial involvement (Phillips, 2008). Recently, the Minnesota Legislature required the Minnesota Ballpark Association and the Minnesota Twins baseball team to work together to construct a stadium that will be able to achieve Leadership in Energy and Environmental Design (LEED) certification.

Other institutional motives leading to environmental initiatives included social expectations that companies be 'green', and the pressure to adopt similar management practices as other successful business entities to attain legitimacy. In this case, it appears that as the diffusion of practices throughout an institutional field grows (i.e., as more firms adopt environmentally responsible programs and initiatives), their validity becomes established (Oliver, I99I). The data from this research suggest that environmental practices are diffusing throughout professional sport at a rapid rate. In fact, $57 \%$ of surveyed participants indicated that league expectations are at the top of the list of factors influencing the adoption of environmental initiatives.

Further analysis of the interview data, intersected with the webpage data, showed that executives representing organizations with high commitment to environmental causes, placed a greater emphasis on strategic motives for engaging in environmentally-focused CSR initiatives (Table 3) than on seeking legitimacy by conforming to institutional pressures. We expected that low engagement organizations may have been motivated to adopt a CSR focus addressing the environment based on institutional motives (i.e., it is the 'right thing to do'; it is a societal expectation), as these organizations had invested fewer 'resources' into their environmental initiatives; however, the data indicated that they, too, were motivated by more strategic imperatives. Pina e Cunha et al. (2008) suggested that organizations go through a transitional phase before arriving at ecocentric management, where companies initially may be inexperienced and insecure (and hesitant when profits are at stake) on how to appropriately handle environmental issues. This may be the case in this study regarding the low engagement organizations.

The findings of this study broaden the focus of environmental CSR from being solely altruistic (it is the right thing to do and a societal expectation) to CSR having dual - organizational and social - benefits and capture a view that links CSR with corporate financial performance (Waddock and Post, I995; Aguilera et al., 2007; Barnett, 2007). That is, it is suggested that a firm can further its strategic interests while expending resources with nothing immediate or obvious in return. Although the firm may not receive tangible, explicit, or discrete exchange value, CSR activities were viewed by respondents as a means to generate intangible strategic assets such as reputational capital (Fombrun et al., 2000; Lewis, 2003) and employee commitment (Turban and Greening, I997; Vogel, 2005) as well as acquiescence among key regulatory institutions or legislative bodies like league governing bodies (Jensen, 2002; Vogel, 2005; Campbell, 2007), the development of the firm's business and institutional environments (Porter and Kramer, 2002), and/or help to mitigate negative media scrutiny (Alsop, 2002; Godfrey et al., 2009).

Our findings suggest that the trend is that organizations will increasingly implement environmental initiatives into their CSR efforts as a strategic necessity to preserve organizational legitimacy in the face of changing social

\begin{tabular}{lcc}
\hline & High commitment & Low engagement \\
\hline Legitimacy motives & $94 \%$ & 60 \\
Strategic motives & 171 & 162
\end{tabular}

Table 3. Legitimacy and strategic motives reported by executives representing high commitment and low engagement sport organizations

$*$ Values represent number of quotations in the coded interview data (i.e., responses of executives) 
values (Vidaver-Cohen and Simcic Brønn, 2008). The activities reported in this research illustrate the strategic application of CSR and thus contribute to the literature by demonstrating this in a particular industry (i.e., professional sport). In addition, efforts to build citizenship may be increasingly important for establishing and maintaining business legitimacy, and for the development of a competitive advantage within the industry.

\section{Conclusions}

There is a growing recognition that the social and environmental challenges facing society are so complex and multidimensional that the only solution is for government, non-profits, and businesses to work together. This study highlights the idea that social responsibility and environmental sustainability are becoming important business practices, not fringe activities in organizations today. It also suggests that for many organizations, environmentally focused CSR appears to be viewed as a value driver with many benefits that are not reflected in traditional financial terms. As Porter and Kramer (2006) stated '... CSR can be much more than a cost, a constraint, or a charitable deed - it can be a source of opportunity, innovation, and competitive advantage'.

Any business - but especially sport businesses given the media scrutiny under which they operate - must have, as a core competency, an ability to create a positive public perception of the organization. This is imperative, considering that consumers expect, as an increasing priority, that companies 'go green'. Promoting green initiatives intends to build the goodwill, and has the potential to increase a businesses' customer base. Professional sport organizations, thus, possess the ability to create revenue streams where none previously existed. Teams have seemingly realized that the prominence of stadia as green building landmarks coincides very well with the general increase in green buildings across the country. As a result, marketing and creating additional revenue streams in connection with the green building elements of the stadium has the promise to be a distinctive and potentially profitable endeavor. The findings of this study have applicability beyond professional sport organizations.

The findings of this study raise a number of important questions. First, in an already crowded marketplace of CSR activities and options, is it reasonable to expect that businesses will focus on another issue within the frame of CSR? At what point should organizations refrain from addressing the 'hot topic' in CSR and instead focus their resources on areas that impact them and in which they can make the most impact? Although we argue that environmental responsibility is an area that certainly is relevant for sport teams and leagues to address, these activities are relatively new and may indeed divert scarce resources away from other worthy socially related causes that these organizations currently focus on.

Relatedly, as Godfrey and Hatch (2007) argued, with '... increasing levels of pressure for transparency in financial dealings and pressure for financial performance ... how should managers analyze and justify CSRs?' Once a firm decides to engage in social initiatives, which CSR activities should the company engage in and how should the organization manage tradeoffs between different spheres of activity? 'Given limited capital resources, and no way to ascertain which projects generate what levels of strategic assets, how are managers to choose, for example, between environmental remediation and remedial reading programs?' (Godfrey and Hatch, 2007). Others argue that companies, even those within the same industry, may gain unique competitive advantages by implementing an aligned portfolio of CSR-related initiatives (Husted and Salazar, 2006). Given the fact that many businesses often address multiple social issues through their CSR initiatives (including the environment, education, health and wellness, to name a few), future research can explore the optimal portfolio for these organizations, one that would provide the most benefit to society and to the organization. Perhaps, more specifically, researchers may examine which sustainable CSR efforts fit into the broader CSR strategy of sport teams and leagues.

Other fruitful avenues to explore include trying to ascertain the degree to which specific practices are adopted in response to changing social values, and testing industry-specific hypotheses about this relationship. There may be particular aspects of CSR that are approaching legitimacy status that differ across industries, which indicates the need for future industry-based research to determine the specific circumstances in which CSR is or is not a common practice.

A company may undertake a strategic CSR approach when it creates an 'opportunity based on a societal issue or trend (e.g., such as marketing 'green' products to consumers in response to environmental issues such as global warming)' (Milliman et al., 2008). 
Future studies should examine patterns of adoption and reporting of sustainable CSR practices, which could be beneficial to organizations that are currently not involved in the area, or who have perhaps shown little regard for issues addressing the environment. When these companies also feel the necessity to include or report on motives to become green, it will be clear that the corporate commitment to sustainability is no longer an option, but rather an expectation or even a requirement.

Most important of all is the question of whether or not the motives and image that a company presents has any relation to its actual performance in environmental CSR (Paul, 2008). This might help with pragmatic issues related to implementing and integrating social responsibility in organizations, including, for example, policies, practices, approaches, issue identification, performance assessment, reporting and communication. Further study of this topic will be instructive in relation to how widely environmental responsibility goals are adopted by businesses, how effectively environmental norms are adopted, how effectively environmental norms are disseminated throughout an industry and how companies put environmental measures into practice.

The findings from this research illustrate that CSR motivations are complex and involve the interplay among a number of different organizational and societal factors. Environmental practices in professional sport are driven by two important considerations - the desire to achieve legitimacy and the strategic or competitive advantages that these types of activities might provide. We acknowledge that the efforts of professional sport organizations alone will not be sufficient to solve environmental problems and challenges, but businesses in combination with other stakeholders will play a major role in the resolution of global environmental problems (Cummins, 2004). We believe that strategic 'green' CSR activities can provide advantages to a professional sport team financially and strategically and simultaneously address a number of other important corporate objectives (i.e., bolster public image, meet needs of key stakeholders, be in alignment with community expectations, and achieve a marketing advantage).

\section{References}

Alsop R. 2002. Perils of corporate philanthropy. Wall Street Journal I6: I-2.

Austin J. 2003. Strategic alliances. Stanford Social Innovation Review I(2): 40-55.

Babiak K, Wolfe R. 2006. More than just a game? Corporate social responsibility and Super Bowl XL. Sport Marketing Quarterly I5: 2I4-222.

Babiak K, Wolfe R. 20I0. Determinants of corporate social responsibility in professional sport: Internal and external factors. Journal of Sport Management 23(6): 7I7-742.

Baughn CC, Bodie NL, McIntosh JC. 2007. Corporate social and environmental responsibility in Asian countries and other geographical regions. Corporate Social Responsibility and Environmental Management I4: 189-205.

Bird RG, Hall AD, Momente F. Reggiani F. 2007. What corporate social responsibility activities are valued by the market? Journal of Business Ethics 76(2): 189-206.

Brietbarth T, Harris P. 2008. The role of corporate social responsibility in the football business: Towards the development of a conceptual model. European Sport Management Quarterly 8(2): 179-206.

Bruch H, Walter F. 2005. The keys to rethinking corporate philanthropy. MIT Sloan Management Review 47(I): 49-55.

Campbell JL. 2006. Institutional analysis and the paradox of corporate social responsibility. The American Behavioral Scientist 49(7): 925-938.

Campbell JL. 2007. Why would corporations behave in socially responsible ways? An institutional theory of corporate social responsibility. Academy of Management Review 32(3): 946-967.

Carroll A. 2000. A commentary and an overview of key questions on corporate social performance measurement. Business and Society 39(4): $466-478$.

Collins A, Flynn A, Munday M, Roberts A. 2007. Assessing the environmental consequences of major sporting events: The 2003/04 FA Cup final. Urban Studies 44(3): 457-476.

Covello L. 2008. Sports teams go green: Real thing or just a fling? FOX Business. Wednesday, 30 January 2008.

Cummins A. 2004. The Marine Stewardship Council: A multi-stakeholder approach to sustainable fishing. Corporate Social Responsibility and Environmental Management II: 85-94.

Deephouse D, Suchman M. 2008. Legitimacy in organizational institutionalism. In Handbook of organizational institutionalism, Greenwood R, Oliver C, Sahlin-Andersson K, Suddaby R (eds). Sage: London; 49-77.

DiMaggio P, Powell WW. I99I. The new institutionalism in organizational analysis. University of Chicago Press: Chicago, IL.

Doh JP, Guay TR. 2006. Corporate social responsibility, public policy, and NGO activism in Europe and the United States: An institutionalstakeholder perspective. Journal of Management Studies 43(I): 47-73.

Fombrun CF, Gardberg NA, Barnett ML. 2000. Opportunity platforms and safety nets: Corporate citizenship and reputational risk. Business and Society Review I05(I): 85-106. 
Font X, Yale K, Tribe J. 200I. Introducing environmental management system in forest recreation: Results from a consultation exercise. Managing Leisure 6: $154-167$.

Galaskiewicz J, Burt RS. I99I. Interorganization contagion in corporate philanthropy. Administrative Science Quarterly 36: 88-I05.

Gimenez Leal G, Casadesus Fa M, Valls Pasola J. 2003. Using environmental management systems to increase firms' competitiveness. Corporate Social Responsibility and Environmental Management Io: IOI-IIo.

Godfrey PC, Hatch NW. 2007. Researching corporate social responsibility: An agenda for the 2Ist century. Journal of Business Ethics 70: $87-98$.

Godfrey PC, Merrill CB, Hansen JM. 2009. The relationship between corporate social responsibility and shareholder value: An empirical test of the risk management hypothesis. Strategic Management Journal 30: 425-445.

Gouldson A. 2006. Do firms adopt lower standards in poorer areas? Corporate social responsibility and environmental justice in the EU and the US. Area 38(4): 402-4I2.

Humphreys B, Ruseski J. 2008. The size and scope of the sports industry in the United States. IASE Conference Papers, o833, International Association of Sports Economists.

Husted B, Salazar J. 2006. Taking Friedman seriously: Maximizing profits and social performance. Journal of Management Studies 43(I): 75-9I.

ISO.org. 2009. International Organization for Standardization 26000. http://isotc.iso.org/livelink/livelink/fetch/2000/2I22/830949/393488 3/3935096/07_gen_info/faq.html [29 December 2009].

Jensen M. 2002. Value maximization, stakeholder theory, and the corporate objective function. Business Ethics Quarterly I2: 235-256.

Kassinis G, Vafeas N. 2006. Stakeholder pressures and environmental performance. Academy of Management Journal 49(I): I45-I59.

Klassen RD, McLaughlin CP. I996. The impact of environmental management on firm performance. Management Science 42(8): II99-I2I4.

Lee K, Ball R. 2003. Achieving sustainable corporate competitiveness: Strategic link between top management's (green) commitment and corporate environmental strategy. GMI 44: 89-104.

Lewis S. 2003. Reputation and corporate responsibility. Journal of Communication Management 7(4): 356-364.

Margolis JD, Walsh JP. 2003. Misery loves companies: Rethinking social initiatives by business. Administrative Science Quarterly 48(2): 268-305.

Matten D, Moon J. 2008. 'Implicit' and 'explicit' CSR: A conceptual framework for a comparative understanding of corporate social responsibility. Academy of Management Review 33(2): 404-424.

McMillan MA, Nekola JC, Larson DW. 2003. Effects of rock climbing on the land snail community of the Niagara escarpment in Southern Ontario, Canada. Conservation Biology I7(2): 616-62I.

McWilliams A, Siegel D. 2000. Corporate social responsibility and financial performance: Correlation or misspecification? Strategic Management Journal 2I(5): 603-609.

Milliman J, Ferguson J, Sylvester K. 2008. Implementation of Michael Porter's strategic corporate social responsibility model. The Journal of Global Business Issues, Conference Edition: 29-33.

Mintzberg H. I984. Who should control the corporation? California Management Review 27(I): 90-II5.

Montiel I. 2008. Corporate social responsibility and corporate sustainability: Separate pasts, common futures. Organization and Environment 2I(3): $245-269$.

Orlitzky M, Schmidt FL, Rynes SL. 2003. Corporate social and financial performance: A meta-analysis. Organization Studies 24(3): 403-440.

Paul K. 2008. Corporate sustainability, citizenship and social responsibility reporting: A website study of Ioo model corporations. The Journal of Corporate Citizenship 32: 63-78.

Pina e Cunha M, Rego A, Vieira da Cunha J. 2008. Ecocentric management: An update. Corporate Social Responsibility and Environmental Management 15: 3II-32I.

Porter ME, Kramer MR. 2006. Strategy and society: The link between competitive advantage and corporate social responsibility. Harvard Business Review 84(12): 78-92.

Porter ME, Kramer MR. 2002.The competitive advantage of corporate philanthropy. Harvard Business Review 80(12): $256-268$.

Rao H. I994. The social construction of reputation: Certification contests, legitimation, and the survival of organizations in the American automobile industry: I895-I912. Strategic Management Journal 15: 29-44.

Sarkar R. 2008. Public policy and corporate environmental behaviour: A broader view. Corporate Social Responsibility and Environmental Management I5: 28I-297.

Scott WR. 2008. Institutions and organizations. 3 rd edn. Sage Publications: Los Angeles, CA.

Sheth H, Babiak K. 20I0. Beyond the game: Perceptions and priorities in corporate social responsibility in the sport industry. Journal of Business Ethics 9I(3): 433-450.

Shively DD, Pape BMC, Mower RN, Zhou Y, Russo R, Sive BC. 2008. Blowing smoke in Yellowstone: Air quality impacts of oversnow motorized recreation in the park. Environmental Management 4I: I83-I99.

Shrivastava P. I995. The role of corporations in achieving ecological sustainability. Academy of Management Review 20(4): 936-960.

Siegele L, Ward H. 2007. Corporate social responsibility: A step towards stronger involvement of business in MEA implementation? RECIEL I6(2): I35-I44.

Smith ACT, Westerbeek HM. 2007. Sport as a vehicle for deploying corporate social responsibility. The Journal of Corporate Citizenship 25: $43-54$.

Suchman MC. I995. Managing legitimacy: Strategic and institutional approaches. Academy of Management Review 20(4): 57I-6Io.

Turban D, Greening D. I997. Corporate social performance and organizational attractiveness to prospective employees. Academy of Management Journal 40: 658-672.

Vidaver-Cohen D, Simcic Brønn P. 2008. Corporate citizenship and managerial motivation: Implications for business legitimacy. Business and Society Review II3(4): 44I-475. 
Vogel D. 2005. The market for virtue. Brookings Institution Press: Washington, DC.

Waddell S. 2000. New institutions for the practice of corporate citizenship: Historical, intersectoral, and developmental perspectives. Business and Society Review I05(I): I07-I27.

Waddock S, Smith N. 2000. Relationships: The real challenge of corporate global citizenship. Business and Society Review I05(I): 47-62.

Wahba H. 2008. Does the market value corporate environmental responsibility? An empirical examination. Corporate Social Responsibility and Environmental Management I5: 89-99.

Welford R, Chan C, Man M. 2007. Priorities for corporate social responsibility: A survey of businesses and their stakeholders. Corporate Social Responsibility and Environmental Management 15: 52-62.

Williamson D, Lynch-Wood G, Ramsay J. 2006. Drivers of environmental behaviour in manufacturing SMEs and the implications for CSR. Journal of Business Ethics 67: 317-330. 